Click www.researchjournal.co.in/online/subdetail.html to purchase.

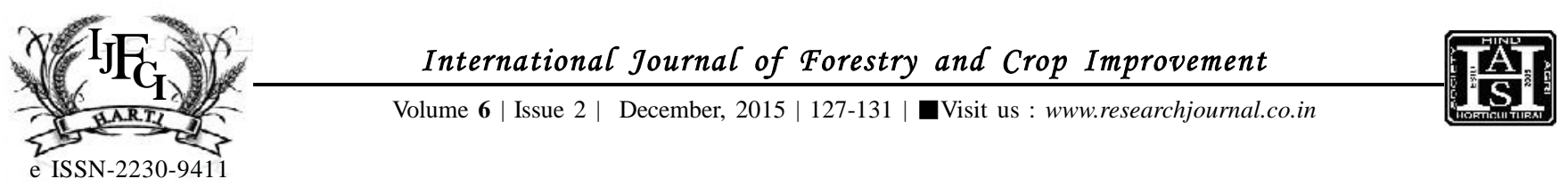

RESEARCH ARTICLE

DOI: $10.15740 / \mathrm{HAS} / \mathrm{IJFCI} / 6.2 / 127-131$

\title{
Performance evaluation of vermicompost on yield of Kharif groundnut and cotton crops
}

\author{
VALLABH N. CHAVDA AND BRIJENDRASINGH RAJAWAT
}

\begin{abstract}
The vermicompost contains plant nutrients including N, P, K, Ca, Mn, Zn and $\mathrm{Cu}$. The uptake of which has a positive effect on plant nutrition, photosynthesis, chlorophyll content in the leaves and improves the nutrient content in different plant component (Root, Shoot etc.). The overall results indicated that organic farming with application of vermicompost @ 3 tons/ hectare in groundnut crop during Kharif 2011-12 to 2013-14 found higher yield, gross return, per cent increase in yield and BC ratio i.e. $2144 \mathrm{~kg} / \mathrm{ha}$, Rs. $80888 /-, 15.39$ per cent and $6.16 \mathrm{BCR}$, respectively as compared to local check yield of $1858 \mathrm{~kg} / \mathrm{ha}$ by application of only of recommended dose of fertilizers. Whereas, application of vermicompost @ 5 tons/hectare in cotton crop resulted during Kharif 2011-12 to 2012-13 produced higher yield, gross return, per cent increase in yield and BC ratio i.e. $3500 \mathrm{~kg} /$ ha, Rs. 172375/-, 14.98 per cent and 4.66 BCR as compared to local check yield of $3044 \mathrm{~kg} / \mathrm{ha}$. Both the crops (groundnut and cotton) were also observed in organically amended plot did not show any moisture stress during the period of dry spell due to better moisture holding. Further, available soil moisture in organically amended plots found better soil moisture conservation compare to local check in pre seasonal or severe moisture stress or in dry spell period. In the nutshell observed that, the use of vermi compost as fertilizer in groundnut as well as cotton crop performed better as compare to using of chemical fertilizers. Therefore, recommended for large scale adoption in farmer's field of Gir Somnath and Junagadh district of Gujarat.
\end{abstract}

KEY WORDS : Vermicompost, Plants growth, Pest incidence, Cotton, Groundnut, Organic waste

How TO CITE THIS ARTICLE : Chavda, Vallabh N. and Rajawat, Brijendra Singh (2015). Performance evaluation of vermicompost on yield of Kharif groundnut and cotton crops. Internat. J. Forestry \& Crop Improv., 6 (2) : 127-131.

Article ChronicAL : Received : 16.09.2015; Revised : 17.11.2015; Accepted : 28.11.2015

MEMBERS OF RESEARCH FORUM

Address of the Correspondence : BRIJENDRA SINGH RAJAWAT, Krishi Vigyan Kendra, JUNAGADH (GUJARAT) INDIA Email: drbsrajawat@gmail.com Address of the Coopted Authors : VALLABH N. CHAVDA, Krishi Vigyan Kendra, JUNAGADH (GUJARAT) INDIA 